\title{
A Brief Review on How Pregnancy and Sex Hormones Interfere with Taste and Food Intake
}

\author{
Marijke M. Faas • Barbro N. Melgert • Paul de Vos
}

Received: 30 May 2009 / Accepted: 7 October 2009 /Published online: 4 November 2009

(C) 2009 The Author(s). This article is published with open access at Springerlink.com

\begin{abstract}
Many physiological and behavioral changes take place during pregnancy, including changes in taste and an increase in food intake. These changes are necessary to ensure growth and development of a healthy fetus. Both hyperphagia and taste changes during pregnancy may be induced by sex hormones estrogen and progesterone that are increased during pregnancy. Indeed, it has been shown that estrogen decreases food intake, while progesterone increases food intake. This is for instance apparent from the fact that food intake changes during the menstrual cycle with variation in sex hormones. This review will give a short overview of the effects of pregnancy and sex hormones on food intake and taste.
\end{abstract}

Keywords Pregnancy · Sex Hormones · Food Intake - Taste · Progesterone $\cdot$ Estrogen

\section{Introduction}

Obesity and associated diseases are fast-growing problems in the Western world. In the past decades the number of obese subjects has reached epidemic proportions and the numbers are still rising (James et al. 2004). The scientific community is fighting obesity and its associated problems by studying means to regulate food intake, including modulating taste and food perception. Although it is extremely important to study the regulation of food intake

M. M. Faas $(\varangle) \cdot$ B. N. Melgert $\cdot$ P. de Vos

Immunoendocrinology, Division of Medical Biology,

Department of Pathology and Medical Biology,

University Medical Centre Groningen,

Hanzeplein 1,

9713 GZ Groningen, The Netherlands

e-mail: m.m.faas@med.umcg.nl in control individuals (or animals), it is equally important to study regulation of food intake during physiological or pathological changes, for instance during pregnancy or during obesity. This is essential to get a full picture of the regulation of food intake. The present review will give a short overview of the present knowledge on changes in taste and food intake during human pregnancy as well as during rat pregnancy, since most experimental studies have been done in this species.

\section{Part I: Pregnancy and Food Intake Regulation}

To ensure growth of the fetus as well as maternal wellbeing, many maternal physiological and behavioral adaptations occur during pregnancy (Campbell-Brown and Hytten 1998; De Swiet 1998; Manyonda 1998). These include immunological adaptations (Manyonda 1998), cardiovascular adaptations (De Swiet 1998), and metabolic adaptations (Campbell-Brown and Hytten 1998). The most profound adaptations are metabolic of nature. The mother has to supply nutrients to the fetus without endangering her own nutrient supply. Moreover, she has to establish a positive energy balance during pregnancy in preparation of the energy demands during lactation (Hytten 1980). The female body has several strategies to meet the increased energy demand such as changes in maternal metabolism, reduced physical activity, and increased food intake (Dufour and Sauther 2002; van Raaij et al. 1987). During human pregnancy in developed countries, it has been shown that food intake is not or only slightly increased (less $10 \%$ of non-pregnancy values) (Durnin 1987). However, in other populations such as in women from Thailand, increases in food intake over $10 \%$ during pregnancy have been found (Durnin 1987). In addition, rats show a large increase in 
food intake during pregnancy, which is about $50 \%$ over non-pregnancy values at the end of pregnancy (Cripps and Williams 1975).

The Effect of Pregnancy on Hormones Involved in Food Intake

The mechanisms that drive the pregnancy-induced increases in appetite and hyperphagia remain largely unknown. The changes may be related to changes in levels of hormones known to regulate food intake, and the most important ones are described below (see also Table 1).

Leptin Leptin is a hormone produced by fat cells and in most cases is produced in proportion to body adiposity. Together with insulin, leptin acts in the hypothalamus to suppress appetite and food intake and it permits energy expenditure (Myers et al. 2007). Surprisingly, during normal human and rat pregnancy, leptin concentrations are increased (Amico et al. 1998; Augustine et al. 2008; Butte et al. 1997; Grattan et al. 2007). This increase has been suggested to be necessary for regulating fetal growth and development and modulating placental endocrine function (Sagawa et al. 2002). Since pregnancy is characterized by hyperphagia and an increased energy demand, it seems likely that a leptin-resistant state develops during pregnancy. This has indeed been shown to be the case in rats (Augustine et al. 2008; Grattan et al. 2007; Ladyman and Grattan 2004; Ladyman and Grattan 2005). Changes in leptin sensitivity may therefore play a role in the hyperphagia during pregnancy in the rat. Whether this also holds true for humans remains to be established.

Ghrelin In the body, plasma ghrelin exists in two forms: acetylated ghrelin and deacyl ghrelin, with acetylated ghrelin being the bioactive form (Hosoda et al. 2000; Murakami et al. 2002). In non-pregnant subjects, ghrelin is primarily secreted by the fundic portion of the stomach. In pregnant women it is also secreted by the placenta (Fuglsang 2008). Ghrelin is an important regulator of the energy balance, e.g., it has been shown to increase food intake (Pusztai et al. 2008). The exact role for ghrelin in pregnancy-induced hyperphagia remains elusive because during human and rat pregnancy basal ghrelin decreases (Makino et al. 2002; Riedl et al. 2007; Shibata et al. 2004; Tham et al. 2009). It may be suggested that the decreased basal ghrelin is a maternal adaptation to the physiological hyperphagia during pregnancy, rather than a regulator of hyperphagia. Additionally or alternatively ghrelin may play a role in fetal development (Nakahara et al. 2006).

Cholecystokinin (CCK) and Peptide YY (PYY) There are only a few studies dedicated to the effect of gut hormones on food intake during human pregnancy. CCK secreted from the duodenum during food intake induces satiety in addition to growth of the pancreas and gastrointestinal function (Geary 2001; Gutzwiller et al. 2000). Basal CCK levels are increased or do not differ in pregnant women as compared with non-pregnant women (Frick et al. 1990; Radberg et al. 1987). However, it is also possible that isoforms of CCK do differ between pregnant and nonpregnant women. Another candidate hormone with a potentially important function in regulating food intake in pregnancy is PYY. PYY is a member of the pancreatic polypeptide family and is produced by the endocrine $\mathrm{L}$ cells in the distal small intestine and colon (Valassi et al. 2008). The main circulating form is PYY3-36 (Karra et al. 2009). This form reduces food intake and prolongs intermeal intervals in several animal models (Valassi et al. 2008). A study in rats demonstrated an increase in PYY levels during pregnancy (Tovar et al. 2004). This suggests that PYY reduces food intake during pregnancy, but pregnancy may also be associated with centrally decreased PYY sensitivity as was described for leptin before (Tovar et al. 2004). More research is needed to elucidate the exact roles of CCK and PYY in the regulation of increased food intake during pregnancy.

Table 1 Function and origin of hormones involved in food intake

\begin{tabular}{lll}
\hline Hormone & Origin & Physiological function \\
\hline Leptin & Fat cells & Suppresses appetite and food intake \\
Ghrelin & Fundic portion of the stomach & Increases food intake \\
Cholecystokinin (CCK) & Duodenum & Induces satiety \\
Peptide YY (PYY) & Endocrine L cells of the small intestine and & $\begin{array}{l}\text { Suppresses food intake and increases intermeal } \\
\text { intervals }\end{array}$ \\
$\alpha$-Melanocyte-stimulating hormone $(\alpha-$ & Arcuate nucleus in the brain & Reduces food intake \\
MSH) & Arcuate nucleus in the brain & Increases food intake \\
Neuropeptide Y (NPY) & Arcuate nucleus in the brain & Increases food intake \\
Agouti-related protein (AgRP) & &
\end{tabular}


$\alpha$-Melanocyte-Stimulating Hormone ( $\alpha$-MSH), Neuropeptide $Y(N P Y)$, and Agouti-Related Protein (AgRP) At the central level, $\alpha$-MSH, NPY, and AgRP are produced in the arcuate nucleus, which branches into various hypothalamic sites that are implicated in regulation of feeding behavior (Bai et al. 1985). These hormones are involved in the control of food intake: $\alpha$-MSH reduces food intake, while NPY and AgRP stimulate food intake (Bai et al. 1985). All three neuropeptides are under the control of amongst others leptin (Arora and Anubhuti 2006). In the arcuate nucleus, leptin induces the expression of proopiomelanocortin, which is a precursor of $\alpha-\mathrm{MSH}$, and suppresses the production of NPY and AgRP (Arora and Anubhuti 2006). During rat pregnancy, not only a leptin-resistant state develops but also an $\alpha$-MSH-resistant state (Ladyman et al. 2009). In other rat models of obesity or hyperphagia, central $\alpha-\mathrm{MSH}$ administration induces decreased food intake (Pierroz et al. 2002; Zhang et al. 2004). This indicates that central $\alpha$-MSH resistance may be specific for pregnancy-induced hyperphagia. In contrast to $\alpha-\mathrm{MSH}$ resistance during rat pregnancy, the production of NPY and AgRP is up-regulated during pregnancy in rats (Garcia et al. 2003; Rocha et al. 2003; Szczepankiewicz et al. 2009). Although the exact mechanisms are unknown, it is plausible that these three neuropeptides are involved in the hyperphagia during pregnancy in the rat.

\section{The Effect of Sex Hormones on Food Intake}

As described above, hyperphagia is a prominent feature of pregnancy in the rat and satiety and satiation signals change during pregnancy. It is also clear that the pregnancyinduced changes in satiety and satiation signals are complex and poorly studied. However, it seems likely that sex hormones are involved, since the increase in food intake is already observed early in pregnancy at a time when the energy demands of the fetus are still limited (CampbellBrown and Hytten 1998; Cripps and Williams 1975; Ladyman and Grattan 2004). Indeed, sex hormones that are important for pregnancy, i.e., progesterone and estrogens, are important modulators of body weight and food intake in rats (Asarian and Geary 2006; Geary and Asarian 1999). It has been shown that progesterone increases food intake, while estrogens decrease food intake (Asarian and Geary 2006). The effect of sex hormones on food intake in rats is also apparent from food intake changes during the rat ovarian cycle (Geary 2001). It seems likely that also in humans food intake is regulated by ovarian hormones, since changes in food intake related to the ovarian cycle have been observed. Women eat less at the periovulatory stage, when estrogens are increased, and they eat more in the luteal phase, when progesterone levels are increased (for a review, see Geary 2001). Moreover, postmenopausal women, which are depleted of estrogens, increase their food intake and therefore usually experience weight gain (Lovejoy 1998, 2003). This increased food intake can be prevented by estrogen treatment (Lovejoy 1998).

The Effect of Sex Hormones on Hormones Involved in Food Intake

Sex hormones have direct effects on food intake and therefore plausibly act on the metabolism of leptin, PYY, ghrelin, and CCK. Only minor information is available on the relation between sex hormones and these food intake regulators. It has been shown in control, untreated animals and premenopausal women that leptin correlated positively with estrogen concentrations (Asarian and Geary 2006). Whether this is a causal effect remains to be confirmed (Asarian and Geary 2006; Lovejoy 1998). In rats, estrogens reportedly increase CCK-induced satiation (Geary 2001) and inhibit the ghrelin-induced increased food intake (Clegg et al. 2007). Since various hypothalamic regions in rats express estrogen and progesterone receptors (Ronnekleiv and Kelly 2005), it is plausible that estrogens and progesterone also affect food intake in the brain at the level of AgRP, NPY, and $\alpha$-MSH in the arcuate nucleus. Some NPY-positive cells also express steroid receptors (Skinner and Herbison 1997). This has been confirmed by studies showing that estrogens downregulate the expression of NPY and AgRP in the rat (Titolo et al. 2006). In addition, the orexigenic effect of NPY, but not of AgRP, is decreased following estrogen treatment of rats (Santollo and Eckel 2008). Unfortunately, the effects of progesterone on these neuropeptides have not been studied yet. However, it seems likely that progesterone is able to increase the production of AgRP and NPY since both neuropeptides are up-regulated during pregnancy in the rat (Garcia et al. 2003; Rocha et al. 2003).

\section{Part II: Pregnancy and Taste Changes}

It is generally accepted that taste changes during human pregnancy. Unfortunately, however, the number of studies dedicated to this subject is very limited. There are some papers on gustatory function during human pregnancy but these studies are often conflicting (Bowen 1992; Brown and Toma 1986; Dippel and Elias 1980; Kuga et al. 2002; Mahomed et al. 1993; Nordin et al. 2004). This can partly be explained by the use of different and incomparable testing methods or different timing during pregnancy. However, consistent results have been found for bitter and salt taste. Various studies have reported a decreased threshold or increased liking for salty taste during human pregnancy as compared with non-pregnant women (Bowen 
1992; Brown and Toma 1986; Duffy et al. 1998; Ochsenbein-Kolble et al. 2005). The decreased taste for salt may be necessary, since pregnant women have an increased salt requirement (Campbell-Brown and Hytten 1998). Similar results have been found in pregnant rats: Pregnant rats ingest more salt during pregnancy and show an increased preference for salt (Pike and Yao 1971; Richter and Barelare 1938), suggesting that the taste threshold for salt is also decreased in pregnant rats (Di Lorenzo and Monroe 1989). A few studies have shown that the sensitivity for bitter taste is increased during human pregnancy (Duffy et al. 1998; Ochsenbein-Kolble et al. 2005). This may be an adaptation to pregnancy in order to avoid intake of bitter-tasting toxic compounds.

It is obvious that there is a significant need for detailed studies on taste changes in pregnancy to understand gustatory function during pregnancy and its possible regulation by sex hormones. A relationship with sex hormones has been suggested from studies in nonpregnant women during menstrual cycle (Bowen and Grunberg 1990; Than et al. 1994). For instance, the threshold for sucrose tasting was lower in the preovulation stage, when estrogen concentrations are high, as compared with the early follicular phase or the luteal phase (Than et al. 1994). This low sucrose threshold during high estrogen concentrations is in line with the finding of an increased sucrose threshold in postmenopausal women, when estrogen concentrations are low as compared with premenopausal women (Delilbasi et al. 2003). These data suggest a role for estrogen in sucrose tasting in humans. Taste differences between females and males have also been studied, again with conflicting results (Cooper et al. 1959; Glanville et al. 1964; Moore et al. 1982; Weiffenbach et al. 1982; Yamauchi et al. 2002).

The fundamental question that remains is the site of action of the sex hormones for inducing taste changes. As described for food intake, sex hormones could directly act in the central nervous system, e.g., in the brainstem, while alternatively estrogens or progesterone may affect taste receptors or taste buds. A human study showed that women have more fungiform papillae and more taste buds than men (Bartoshuk et al. 1994). A study in rats showed that changes in taste bud morphology occur during pregnancy (Yucel et al. 2002). Electron microscopical scanning of the lingual papillae of pregnant rats showed differences in topographical configurations of these papillae as compared to those of control rats (Yucel et al. 2002). Also in rat studies, at the level of the brainstem, some gender differences have been shown in the strength of the response to certain stimuli of the parabrachial pons (Di Lorenzo and Monroe 1989). Female rats had a greater response to sweet stimuli in the parabrachial pons than male rats (Di Lorenzo and Monroe 1989), while the responses to sweet stimuli were even further increased in pregnant rats as compared with non-pregnant females (Di Lorenzo and Monroe 1989). An effect of sex hormones on the parabrachial pons of female rats has been shown when control female rats were compared with ovariectomized female rats. It was shown that the response of the parabrachial pons to bitter taste was increased in ovariectomized rats as compared with control female rats (Di Lorenzo and Monroe 1990). These experimental studies show that sex hormones probably affect taste both at the level of the taste buds as well as in the central nervous system.

\section{Summary and Conclusion}

Although increased food intake during pregnancy may be limited in humans in developed countries (Durnin 1987), women in less developed countries, such as Thai women (Thongprasert et al. 1987), do increase their food intake during pregnancy. Additionally, rats increase their food intake by $50 \%$ during pregnancy (Cripps and Williams 1975; Ladyman and Grattan 2004). As described in this paper, not only food intake increases during pregnancy but also taste preferences change, and this may induce differences in food intake during normal pregnancy. The mechanisms by which food intake and taste changes are induced are relatively unknown. In rats it seems likely that the sex hormones affect food intake at the level of the brain, i.e., by increasing NPY and AgRP and by increasing leptin resistance. For human pregnancy it is unclear whether these data from rats can be extrapolated, since food intake was only slightly increased in pregnant women. However, since an effect of sex hormones on food intake in humans has been shown it seems likely that similar mechanisms may induce increased food intake in human pregnancy, although at a lower magnitude. Therefore further studies are mandatory to elucidate the role of sex hormones in regulating food intake in rats and humans and in pregnancy.

Although it is generally accepted that taste changes occur during pregnancy, the scientific evidence for taste changes during pregnancy are largely lacking. To combat the obesity epidemic we need to increase our knowledge of satiety, satiation signals, and taste changes in control individuals as well as in individuals with hyperphagia like obese people or pregnant women. It may be clear from the above that pregnancy is an excellent physiological model to study changes in the regulation of food intake, satiety, satiation signals, and taste changes. The advantage of using pregnancy as a model for hyperphagia is that changes in satiety/satiation signals and food intake take place in a relatively small and well-defined time frame.

This review emphasizes that when studying changes in food intake and taste, the role of sex hormones needs to be 
taken into account. Food intake and taste changes in women vary with their hormonal status. It is therefore imperative when studying food intake and taste to stratify according to gender and to take menstrual cycle, oral contraceptive use, and age (i.e., menopause) into account when studying women.

Open Access This article is distributed under the terms of the Creative Commons Attribution Noncommercial License which permits any noncommercial use, distribution, and reproduction in any medium, provided the original author(s) and source are credited.

\section{References}

Amico JA, Thomas A, Crowley RS, Burmeister LA (1998) Concentrations of leptin in the serum of pregnant, lactating, and cycling rats and of leptin messenger ribonucleic acid in rat placental tissue. Life Science 63(16):1387-1395

Arora S, Anubhuti (2006) Role of neuropeptides in appetite regulation and obesity - a review. Neuropeptides 40(6):375-401

Asarian L, Geary N (2006) Modulation of appetite by gonadal steroid hormones. Philosophical Transaction of the Royal Society B: Biological Science 361(1471):1251-1263

Augustine RA, Ladyman SR, Grattan DR (2008) From feeding one to feeding many: hormone-induced changes in bodyweight homeostasis during pregnancy. J Physiol 586(Pt 2):387-397

Bai FL, Yamano M, Shiotani Y, Emson PC, Smith AD, Powell JF, Tohyama M (1985) An arcuato-paraventricular and -dorsomedial hypothalamic neuropeptide Y-containing system which lacks noradrenaline in the rat. Brain Res 331(1):172-175

Bartoshuk LM, Duffy VB, Miller IJ (1994) PTC/PROP tasting: anatomy, psychophysics, and sex effects. Physiology and Behaviour 56(6): 1165-1171

Bowen DJ (1992) Taste and food preference changes across the course of pregnancy. Appetite 19(3):233-242

Bowen DJ, Grunberg NE (1990) Variations in food preference and consumption across the menstrual cycle. Physiology and Behaviour 47(2):287-291

Brown JE, Toma RB (1986) Taste changes during pregnancy. American Journal of Clinical Nutrition 43(3):414-418

Butte NF, Hopkinson JM, Nicolson MA (1997) Leptin in human reproduction: serum leptin levels in pregnant and lactating women. Journal of Clinical Endocrinol and Metabolism 82 (2):585-589

Campbell-Brown M, Hytten F (1998) Nutrition. In: Chamberlain G, Broughton Pipkin F (eds) Clinical physiology in obstetrics. Blackwell Science, Oxford, pp 165-191

Clegg DJ, Brown LM, Zigman JM, Kemp CJ, Strader AD, Benoit SC, Woods SC, Mangiaracina M, Geary N (2007) Estradioldependent decrease in the orexigenic potency of ghrelin in female rats. Diabetes 56(4):1051-1058

Cooper RM, Bilashi I, Zubek JP (1959) The effect of age on taste sensitivity. J Gerontol 14(1):56-58

Cripps AW, Williams VJ (1975) The effect of pregnancy and lactation on food intake, gastrointestinal anatomy and the absorptive capacity of the small intestine in the albino rat. Br J Nutr 33(1):17-32

De Swiet M (1998) The cardiovascular system. In: Chamberlain G, Broughton Pipkin F (eds) Clinical physiology in obstetrics. Blackwell Science, Oxford, pp 33-70

Delilbasi C, Cehiz T, Akal UK, Yilmaz T (2003) Evaluation of gustatory function in postmenopausal women. Br Dent J 194 (8):447-449
Di Lorenzo PM, Monroe S (1989) Taste responses in the parabrachial pons of male, female and pregnant rats. Brain Res Bull 23 (3):219-227

Di Lorenzo PM, Monroe S (1990) Taste responses in the parabrachial pons of ovariectomized rats. Brain Res Bull 25(5):741-748

Dippel RL, Elias JW (1980) Preferences for sweet in relationship to use of oral contraceptives and pregnancy. Hormones \& Behaviour 14(1): 1-6

Duffy VB, Bartoshuk LM, Striegel-Moore R, Rodin J (1998) Taste changes across pregnancy. Ann N Y Acad Sci 855:805-809

Dufour DL, Sauther ML (2002) Comparative and evolutionary dimensions of the energetics of human pregnancy and lactation. Am J Hum Biol 14(5):584-602

Durnin JV (1987) Energy requirements of pregnancy: an integration of the longitudinal data from the five-country study. Lancet 2 (8568):1131-1133

Frick G, Bremme K, Sjogren C, Linden A, Uvnas-Moberg K (1990) Plasma levels of cholecystokinin and gastrin during the menstrual cycle and pregnancy. Acta Obstetricia Gynecologica Scandinavia 69(4):317-320

Fuglsang J (2008) Ghrelin in pregnancy and lactation. Vitam Horm 77:259-284

Garcia MC, Lopez M, Gualillo O, Seoane LM, Dieguez C, Senaris RM (2003) Hypothalamic levels of NPY, MCH, and preproorexin mRNA during pregnancy and lactation in the rat: role of prolactin. FASEB J 17(11):1392-1400

Geary N (2001) Estradiol, CCK and satiation. Peptides 22(8):12511263

Geary N, Asarian L (1999) Cyclic estradiol treatment normalizes body weight and test meal size in ovariectomized rats. Physiology and Behaviour 67(1):141-147

Glanville EV, Kaplan AR, Fischer R (1964) Age, sex, and taste sensitivity. J Gerontol 19:474-478

Grattan DR, Ladyman SR, Augustine RA (2007) Hormonal induction of leptin resistance during pregnancy. Physiology and Behaviour 91(4):366-374

Gutzwiller JP, Drewe J, Ketterer S, Hildebrand P, Krautheim A, Beglinger C (2000) Interaction between CCK and a preload on reduction of food intake is mediated by CCK-A receptors in humans. Am J Physiol Regul Integr Comp Physiol 279(1):R189-R195

Hosoda H, Kojima M, Matsuo H, Kangawa K (2000) Ghrelin and desacyl ghrelin: two major forms of rat ghrelin peptide in gastrointestinal tissue. Biochemical Biophysical Research Communications 279(3):909-913

Hytten F (1980) Weight gain in pregnancy. In: Hytten F, Chamberlain $\mathrm{G}$ (eds) Clinical physiology in obstetrics. Blackwell Scientific, Oxford, pp 193-233

James PT, Rigby N, Leach R (2004) The obesity epidemic, metabolic syndrome and future prevention strategies. Eur J Cardiovasc Prev Rehabil 11(1):3-8

Karra E, Chandarana K, Batterham RL (2009) The role of peptide YY in appetite regulation and obesity. J Physiol 587(Pt 1):19-25

Kuga M, Ikeda M, Suzuki K, Takeuchi S (2002) Changes in gustatory sense during pregnancy. Acta Otolaryngology 122(Suppl 546):146-153

Ladyman SR, Grattan DR (2004) Region-specific reduction in leptininduced phosphorylation of signal transducer and activator of transcription-3 (STAT3) in the rat hypothalamus is associated with leptin resistance during pregnancy. Endocrinology 145 (8):3704-3711

Ladyman SR, Grattan DR (2005) Suppression of leptin receptor messenger ribonucleic acid and leptin responsiveness in the ventromedial nucleus of the hypothalamus during pregnancy in the rat. Endocrinology 146(9):3868-3874

Ladyman SR, Tups A, Augustine RA, Swahn-Azavedo AM, Kokay IC, Grattan DR (2009) Loss of hypothalamic response to leptin 
during pregnancy associated with development of melanocortin resistance. J Neuroendocrinol 21:449-456

Lovejoy JC (1998) The influence of sex hormones on obesity across the female life span. Journal of Womens Health 7(10):1247-1256

Lovejoy JC (2003) The menopause and obesity. Primary Care 30 (2):317-325

Mahomed K, James D, Golding J, McCabe R (1993) Failure to taste zinc sulphate solution does not predict zinc deficiency in pregnancy. Eur J Obstet Gynecol Reprod Biol 48(3):169-175

Makino Y, Hosoda H, Shibata K, Makino I, Kojima M, Kangawa K, Kawarabayashi $\mathrm{T}$ (2002) Alteration of plasma ghrelin levels associated with the blood pressure in pregnancy. Hypertension 39 (3):781-784

Manyonda IT (1998) The Immune System. In: Chamberlain G, Broughton Pipkin F (eds) Clinical physiology in obstetrics. Blackwell Science, Oxford, pp 129-164

Moore LM, Nielsen CR, Mistretta CM (1982) Sucrose taste thresholds: age-related differences. J Gerontol 37(1):64-69

Murakami N, Hayashida T, Kuroiwa T, Nakahara K, Ida T, Mondal MS, Nakazato M, Kojima M, Kangawa K (2002) Role for central ghrelin in food intake and secretion profile of stomach ghrelin in rats. J Endocrinol 174(2):283-288

Myers MG, Cowley MA, Munzberg H (2007) Mechanisms of leptin action and leptin resistance. Annu Rev Physiol 70:537-556

Nakahara K, Nakagawa M, Baba Y, Sato M, Toshinai K, Date Y, Nakazato M, Kojima M, Miyazato M, Kaiya H, Hosoda H, Kangawa K, Murakami N (2006) Maternal ghrelin plays an important role in rat fetal development during pregnancy. Endocrinology 147(3):1333-1342

Nordin S, Broman DA, Olofsson JK, Wulff M (2004) A longitudinal descriptive study of self-reported abnormal smell and taste perception in pregnant women. Chem Senses 29(5):391-402

Ochsenbein-Kolble N, Ochsenbein-Kolble N, von Zimmermann MRR, Hummel T (2005) Changes in gustatory function during the course of pregnancy and postpartum. Br J Obstet Gynaecol 112(12):1636-1640

Pierroz DD, Ziotopoulou M, Ungsunan L, Moschos S, Flier JS, Mantzoros CS (2002) Effects of acute and chronic administration of the melanocortin agonist MTII in mice with diet-induced obesity. Diabetes 51(5):1337-1345

Pike RL, Yao C (1971) Increased sodium chloride appetite during pregnancy in the rat. J Nutr 101(2):169-175

Pusztai P, Sarman B, Ruzicska E, Toke J, Racz K, Somogyi A, Tulassay Z (2008) Ghrelin: a new peptide regulating the neurohormonal system, energy homeostasis and glucose metabolism. Diabetes Metab Res Rev 24(5):343-352

Radberg G, Rehfeld JF, Cantor P, Jarnfelt-Samsioe A, Samsioe G, Asztely M, Svanvik J (1987) Cholecystokinin secretion in pregnancy. Scand J Gastroenterol 22(6):687-690

Richter CP, Barelare B (1938) Nutritional requirements of pregnant and lactating rats studied by the self-selection method. Endocrinology 23:15-24

Riedl M, Maier C, Handisurya A, Luger A, Kautzky-Willer A (2007) Insulin resistance has no impact on ghrelin suppression in pregnancy. J Intern Med 262(4):458-465

Rocha M, Bing C, Williams G, Puerta M (2003) Pregnancy-induced hyperphagia is associated with increased gene expression of hypothalamic agouti-related peptide in rats. Regul Pept 114(23):159-165
Ronnekleiv OK, Kelly MJ (2005) Diversity of ovarian steroid signaling in the hypothalamus. Frontieres in Neuroendocrinology 26(2):65-84

Sagawa N, Yura S, Itoh H, Mise H, Kakui K, Korita D, Takemura M, Nuamah MA, Ogawa Y, Masuzaki H, Nakao K, Fujii S (2002) Role of leptin in pregnancy - a review. Placenta 23(Suppl A):S80-S86

Santollo J, Eckel LA (2008) Estradiol decreases the orexigenic effect of neuropeptide Y, but not agouti-related protein, in ovariectomized rats. Behav Brain Res 191(2):173-177

Shibata K, Hosoda H, Kojima M, Kangawa K, Makino Y, Makino I, Kawarabayashi T, Futagami K, Gomita Y (2004) Regulation of ghrelin secretion during pregnancy and lactation in the rat: possible involvement of hypothalamus. Peptides 25(2):279-287

Skinner DC, Herbison AE (1997) Effects of photoperiod on estrogen receptor, tyrosine hydroxylase, neuropeptide $\mathrm{Y}$, and betaendorphin immunoreactivity in the ewe hypothalamus. Endocrinology 138(6):2585-2595

Szczepankiewicz D, Pruszynska-Oszmalek E, Kaczmarek P, Skrzypski M, Andralojoc K, Wojciechowicz T, Sassek M, Nowak KW (2009) Changes of agouti-related protein in hypothalamus, placenta, and serum during pregnancy in the rat. $\mathrm{J}$ Endocrinol 202(1):35-41

Tham E, Liu J, Innis S, Thompson D, Gaylinn BD, Bogarin R, Haim A, Thorner MO, Chanoine JP (2009) Acylated ghrelin concentrations are markedly decreased during pregnancy in mothers with and without gestational diabetes: relationship with cholinesterase. Am J Physiol: Endocrinol Metab 296(5):E1093-E1100

Than TT, Delay ER, Maier ME (1994) Sucrose threshold variation during the menstrual cycle. Physiology and Behaviour 56 (2):237-239

Thongprasert K, Tanphaichitre V, Valyasevi A, Kittigool J, Durnin JV (1987) Energy requirements of pregnancy in rural Thailand. Lancet 2(8566):1010-1012

Titolo D, Cai F, Belsham DD (2006) Coordinate regulation of neuropeptide $\mathrm{Y}$ and agouti-related peptide gene expression by estrogen depends on the ratio of estrogen receptor (ER) alpha to ERbeta in clonal hypothalamic neurons. Mol Endocrinol 20 (9):2080-2092

Tovar SA, Seoane LM, Caminos JE, Nogueiras R, Casanueva FF, Dieguez C (2004) Regulation of peptide YY levels by age, hormonal, and nutritional status. Obes Res 12(12):1944-1950

Valassi E, Scacchi M, Cavagnini F (2008) Neuroendocrine control of food intake. Nutrition, Metabolism and Cardiovascular Disease 18(2):158-168

van Raaij JM, Vermaat-Miedema SH, Schonk CM, Peek ME, Hautvast JG (1987) Energy requirements of pregnancy in The Netherlands. Lancet 2(8565):953-955

Weiffenbach JM, Baum BJ, Burghauser R (1982) Taste thresholds: quality specific variation with human aging. J Gerontol 37 (3):372-377

Yamauchi Y, Endo S, Yoshimura I (2002) A new whole-mouth gustatory test procedure. II. Effects of aging, gender and smoking. Acta Otolaryngology 546:49-59

Yucel F, Akdogan I, Guven G, Ortug G (2002) SEM examination of the dorsal lingual papillae of pregnant rats. Annals of Anatomy 184(3):251-255

Zhang Y, Matheny M, Tumer N, Scarpace PJ (2004) Aged-obese rats exhibit robust responses to a melanocortin agonist and antagonist despite leptin resistance. Neurobiol Aging 25(10):1349-1360 